\title{
PREVALENCE OF TICK INFESTATION IN DIFFERENT BREEDS OF CATTLE IN MAIDUGURI, NORTHEASTERN NIGERIA
}

\author{
H. I. Musa ${ }^{1}$, S. M. Jajere ${ }^{1 *}$, N. B. Adamu ${ }^{1}$, N. N. Atsanda ${ }^{1}$, J. R. Lawal ${ }^{2}$, S. G. Adamu ${ }^{1}$, E. K. Lawal ${ }^{1}$ \\ ${ }^{1}$ Department of Veterinary Public Health and Preventive Medicine, Faculty of Veterinary Medicine, University \\ of Maiduguri, P M B 1069, Maiduguri, Borno State, Nigeria \\ ${ }^{2}$ Department of Veterinary Medicine, Faculty of Veterinary Medicine, University of Maiduguri, P M B 1069, \\ Maiduguri, Borno State, Nigeria
}

\begin{abstract}
A survey study was conducted from June to December 2009 using standard parasitological procedures to determine the prevalence of tick infestation among cattle of different breeds in Maiduguri, Northeastern Nigeria. The tick species identified were Boophilus microplus, Amblyomma variegatum, Hyalomma spp., Rhipicephalus sanguineous and Ornithodorus spp. Of the 205 cattle examined, $63.4 \%$ (95\% CI: $56.8-70.0)$ were tick infested. Males had a non - significantly $(P>0.05)$ higher infestation rate of $63.4 \%(56.7-71.7)$ compared with the females $60.9 \%(46.8-75.0)$. Younger animals aged $\leq 3$ years had a significantly $(P<0.05)$ higher prevalence of $85.4 \%(74.6-96.2)$ as compared with the adults aged $>3-7$ years $55.8 \%(46.3$ $-65.3)$ and older animals $>7$ years $35.0 \%(22.9-47.1)$. Among breeds, Wadara and Kuri had significantly $(P<0.05)$ higher infestation rates of $66.1 \%(57.9-74.3)$ and $66.7 \%$ (13.4 - 120.0) respectively. Gudali had $60.9 \%$ (41.0 - 80.8), Rahaji $58.0 \%$ (44.3 - 71.7) and Bunaji 50.0\% (19.3 - 119.3). Based on the predilection sites, the udder and external genitalia, inner thigh and under the tail/perineum were the most tick-infested sites with $84.3 \%$ (78.3 - 88.5), 79.0\% (73.4 - 84.6) and 69.8\% (63.5$76.1)$ respectively $(P<0.05)$. While the less preferred sites eyes, neck/dewlap, ears and all over the body each had prevalence of $26.3 \%(20.3-32.3), 14.6 \%(9.8-1.4), 12.2 \%(7.7-16.7)$ and $11.2 \%(6.9-15.5)$ respectively. This study reveals high prevalence of tick infestation among indigenous cattle in Maiduguri. This might hamper cattle production and productivity in Nigeria. Thus, it is recommended that appropriate control strategies be instituted to control ticks in the study area.
\end{abstract}

Key words: Maiduguri, Northeastern Nigeria, Prevalence, Cattle, Ticks

\section{INTRODUCTION}

Nigeria's livestock population was recently estimated at 34.5 million goats, 22.1 million sheep and 13.9 million cattle populations (RIM, 1992). Of the 13.9 million heads of cattle, about 11.5 million were kept in pastoral systems, while the remaining 2.4 million were kept in villages (RIM, 1992). A larger proportion of these animals are largely concentrated in the northern than the southern region of the country. Specifically, about $90 \%$ of cattle population are concentrated in the northern region. Borno state, a Northeastern region in Nigeria, is estimated to harbour about 2.4 million heads of cattle (Anonymous, 1996). Despite the concentration of cattle population in the Northern region of Nigeria, cattle production and productivity has been hampered by low or poor husbandry practices, inadequate feed supply and disease constraints particularly ectoparasitic infestations, thereby limiting the protein supply in Nigerian diets (Oyenaya And Olibajo, 1977). Among the ectoparasitic infestations, ticks remain one of the most economically important parasites of cattle in tropical and subtropical countries (Jongejan And Uilenberg, 1994). Ticks rank second to insects as vectors of transmissible diseases in man and animals (Opara And Ezeh, 2011). Bowman et al. (1996) estimated more than 80\% of world cattle population is infested by ticks, which are known to transmit viral, bacterial and protozoan pathogens causing Tick Borne Diseases (TBD) such as hemorrhagic fever, cowdriosis, ehrlichiosis, anaplasmosis, theileriosis and babesiosis (Rajput $e t$ al., 2006). Ticks suck blood of their hosts resulting into severe anemia, loss of production, weakness and immunosuppression (Gwakisa et al., 2001) as well as damages hides and skin leading to significant financial losses to livestock farmers (Biswas, 2003). Production losses due to ticks and tick-borne diseases (TBD) around the globe were put at US\$13.9 to US\$18.7 billion annually (de Wall, 2000; de Castro, 1997). There are currently little studies on the prevalence and epidemiology of ticks commonly affecting cattle production in Maiduguri, despite the fact that it is endowed with favourable weather condition suitable for the proliferation

*Corresponding e-mail address: drmsalehjajere@gmail.com 


\section{H. I. Musa and others}

and multiplication of ticks as well as serving as a focal point of cattle concentration in the Northeastern Nigeria. Therefore, this necessitates the need for this study on the prevalence of ticks among cattle of different breeds in Maiduguri, Nigeria.

\section{MATERIALS AND METHODS \\ Study area}

Maiduguri is one of the six Northeastern states of Nigeria located within the Sahel savannah zone. It occupies the greater part of the Chad Basin and is located at $11^{\circ} 50^{\mathrm{I}}-11.83^{\circ}$ North Latitude and $13^{\circ} 09^{\mathrm{I}}-13.15^{\circ}$ East Longitude. It shares border with Republics of Niger to the North, Chad to the Northeast, Cameroon to the East and Yobe State to the West. The climate is hot and dry for a greater part of the year with rainy season from June to September in the Northern part and May to October in the Southern part (Opara and Ezeh, 2011) with a mean annual rainfall and temperature of about $650 \mathrm{~mm}$ and $32^{\circ} \mathrm{C}$ respectively.

\section{Study Population and Sampling Method}

A total of 205 cattle comprising White Fulani, Wadara, Rahaji, Gudali, Kuri and Bunaji breeds were randomly selected from Maiduguri livestock market and central abattoir and were examined within the period of June to December 2009.

\section{Sample Collection and Preservation}

The selected cattle were thoroughly examined, parting the hairs against their natural direction for the detection of ticks. Age was determined by asking the owner and farm attendants, visual inspection and by dentition whenever possible. Animals were categorized based on age as young ( $\leq 3$ years), adult ( $>3-7$ years) and old (> 7 years). Sex was also determined at the time of collecting the samples. Ticks were collected from different parts of the body including the Neck/dewlap, eyes, ear, udder and external genitalia, Inner thighs, under the tail/perineum and legs/interdigital spaces by using forceps and hand gloves. When required, small hairbrush dipped in ethanol was used for the collection of the ticks. The point of attachment was smeared with ethanol. Adequate precautions were taken to preserve the mouthparts and some appendages of the ticks during collection to help in the identification. The ticks collected were put into clean, properly labeled and well-stopper glass vials containing 70\% alcohol and 5\% glycerol for preservation. The vials were immediately transported to the Department of Veterinary Microbiology and Parasitology, University of Maiduguri for further analysis and identification.

\section{Tick identification}

Ticks collected were examined under low power and then high power magnification of microscope. The morphology of the ticks was studied in the laboratory using dissecting and compound microscopes. Identification of the different species of the ticks was accomplished with the help of the anatomical and morphological characteristics as described by Soulsby (1982).

\section{Statistical analysis}

The raw data was compiled and managed in Microsoft excel 2007. Prevalence was estimated using the method described by Thrusfield (1995). A chi - square test was used to determine the statistical significance and association between the disease and other independent variables. A 95\% Confidence Interval on the estimated prevalences was also estimated and $\mathrm{P}<0.05$ was considered statistically significant. All statistical analyses for the present study were carried out using Graphad Instat version 17.0 statistical software.

\section{RESULTS AND DISCUSSION}

Out of the 205 animals examined, 130 cattle representing 63.4\% (95\% CI: $56.8-70.0$ ) were tick infested (Table 1). Sex - wise prevalence reveals males having slightly higher prevalence of $64.2 \%(56.7-71.7)$ compared with the females $60.9 \%$ (46.8 - 75.0) (Table 1). However, the prevalence of tick infestation is non significant $(P>0.05)$ among animals of either sex. Younger animals aged $\leq 3$ years had the highest prevalence of $85.4 \%$ (74.6-96.2) compared with adults aged $>3-7$ years $55.8 \%(46.3-65.3)$ and the lowest was seen in 
older cattle aged $>7$ years with $35.0 \%(22.9-47.1)$ (Table 1). The prevalence of tick infestation is significant $(\mathrm{P}<0.05)$ among the different age groups. Based on breeds, Wadara and Kuri had the highest prevalence of tick infestations of $66.1 \%(57.9-74.3)$ and $66.7 \%$ (13.4 - 120.0) respectively. While Rahaji, Gudali and Bunaji had $58.0 \%$ (44.3 - 71.7), 60.9\% (41.0 - 80.8) and 50.0\% (19.3 - 119.3) respectively (Table 1). The prevalence of tick infestation was significant $(\mathrm{P}<0.05)$ among cattle of different breeds. Various body parts of the sampled animals were examined to determine the predilection sites of tick infestations. This reveals that udder and external genitalia, inner thighs and under the tail/perineum were the most tick infested sites having 83.4\%, 79.0\%, and $69.8 \%$ respectively (Table 2$)$. This is followed by eyes (26.3\%), Neck/dewlap (14.6\%), Ears (12.2\%) and all over the body $(11.2 \%)$ in descending order of tick infestation (Table 2). The prevalence of tick infestation was significant $(\mathrm{P}<0.05)$ among the different predilection sites examined. The prevalence of tick infestations among cattle examined in the present study revealed that $63.4 \%$ of the total observed animals were found tick infested. This reveals a high tick infestation rates among cattle in Maiduguri. Several studies documented similar higher prevalence in Maiduguri (James - Rugu and Jidayi, 2004; Opara and Ezeh, 2011), other regions of Nigeria (Agbede, 1981; Onyali et al., 1989; Obadiah and Shekaro, 2012) and other parts of the world (Islam et al., 2009; Rony et al., 2010).

Table 1. Prevalence of tick infestation according to sex, age and breeds in cattle in Maiduguri, Northeastern Nigeria $(n=205)$

\begin{tabular}{|c|c|c|c|c|}
\hline Risk factors & & No. examined & No. $(\%)$ infested & $95 \% \mathrm{CI}^{1}$ \\
\hline \multirow[t]{2}{*}{ Sex } & Male & 159 & $102(64.2)^{\mathrm{a}}$ & $56.7-71.7$ \\
\hline & Female & 46 & $28(60.9)$ & $46.8-75.0$ \\
\hline \multirow[t]{3}{*}{ Age } & Young ( $\leq 3 \mathrm{yrs})$ & 41 & $35(85.4)^{\mathrm{b}}$ & $74.6-96.2$ \\
\hline & Adult (>3-7yrs) & 104 & $58(55.8)$ & $46.3-65.3$ \\
\hline & Old (>7yrs) & 60 & $21(35.0)$ & $22.9-47.1$ \\
\hline \multirow[t]{5}{*}{ Breed } & Wadara & 127 & $84(66.1)^{b}$ & $57.9-74.3$ \\
\hline & Rahaji & 50 & $29(58.0)$ & $44.3-71.7$ \\
\hline & Gudali & 23 & $14(60.9)$ & $41.0-80.8$ \\
\hline & Kuri & 3 & $2(66.7)$ & $13.4-120.0$ \\
\hline & Bunaji & 2 & $1(50.0)$ & $19.3-119.3$ \\
\hline Total & & 205 & $130(63.4)$ & $56.8-70.0$ \\
\hline
\end{tabular}

Table 2. Prevalence of tick infestation in different body parts of examined cattle in Maiduguri, Northeastern Nigeria $(n=205)$

\begin{tabular}{lll}
\hline Predilection sites & No. of cattle infested & Prevalence \% $\left(95 \% \mathrm{CI}^{1}\right)$ \\
\hline Neck/dewlap & 30 & $14.6(9.8-1.4)^{\mathrm{a}}$ \\
Ears & 25 & $12.2(7.7-16.7)$ \\
Around eyes & 54 & $26.3(20.3-32.3)$ \\
Udder and external genitalia & 171 & $83.4(78.3-88.5)$ \\
Inner thighs & 162 & $79.0(73.4-84.6)$ \\
Under the tail/perineum & 143 & $69.8(63.5-76.1)$ \\
All over the body & 23 & $11.2(6.9-15.5)$ \\
\hline
\end{tabular}

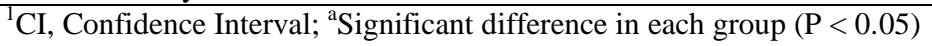

The findings in this study of Boophilus microplus, Amblyomma variegatum, Hyalomma spp., Rhipicephalus sanguineous and Ornithodorus spp. infesting cattle is in line with reports by Opara and Ezeh (2011) who identified these ticks in addition to Dermacentor variabilis in Borno and Yobe States, Northeastern Nigeria; James-Rugu and Jidayi (2004) in Northeastern Nigeria; Amoo et al. (1984) in South-western Nigeria; Mohammed (1976) in North central Nigeria and Okon and Obiekazie (1981) who identified and describes them 


\section{H. I. Musa and others}

as vectors of livestocks and haemoparasitic diseases. Similar observations were reported from other parts of the world (Atif et al., 2012; Asmaa et al., 2014). The predominance of these ticks mainly belonging to the family Ixodidae (hard ticks) in Maiduguri could be attributed to the high temperature in this region, which makes it unfavourable for the survival of soft ticks (Opara and Ezeh, 2011).

Table 3. Predilection sites and species of ticks recovered among cattle in Maiduguri, Northeastern Nigeria

\begin{tabular}{ll}
\hline Sites of recovery & Tick species identified \\
\hline Neck/dewlap & Boophilus microplus \\
Around eyes & Amblyomma variegatum \\
Ears & Hyalomma spp. \\
& Amblyomma variegatum \\
& Rhipicephalus sanguineous \\
Udder and external genitalia & Boophilus microplus \\
& Hyalomma spp. \\
& Amblyomma variegatum \\
& Hyalomma spp. \\
Legs/interdigital spaces & Rhipicephalus sanguineous \\
& Amblyomma variegatum \\
& Boophilus microplus \\
Under the tail/perineum & Hyalomma spp. \\
& Boophilus microplus \\
& Rhipicephalus sanguineous \\
& Rhipicephalus sanguineous \\
Inner thighs & Boophilus microplus \\
& Amblyomma variegatum \\
& Ornithodorus spp. \\
& Hyalomma spp. \\
& Boophilus microplus \\
& Hyalomma spp. \\
& Amblyomma variegatum \\
\hline
\end{tabular}

Males were found to have a slightly higher tick infestation rates compared with the female cattle. This result is in line with reports by Opara and Ezeh (2011) and Hitcheock (1993) who reported that males are more infested with ticks than female cattle, because most of the males in the tropics are mainly used for most of the farming activities and moved from place to place in search of food and in the process get infested with ticks, while the females are mainly confined for breeding purposes and therefore are less exposed to tick infestations in the tropics. Larvae of ticks are known to climb blades of grasses and shrubs to attach themselves to passing hosts mostly males during grazing (Soulsby, 1982). However, it is not in agreement with the works of Asmaa et al. (2014), Rony et al. (2010) and Sarkar (2007) where both reported a significantly higher prevalence of ectoparasitic infestations in female than the male cattle. Infestation rate was higher in younger animals aged $\leq 3$ years and the lowest was seen in older animals aged $>7$ years (Table 1). This is in concordance with the works of Manan et al. (2007), who found that resistance in the animals was building up as the animals grow up and the animals became more resistant and adoptable than in younger stage irrespective of the farm species. Islam et al. (2009) in the same vein found that calves were 2.0 times more susceptible to tick infestation more than the adults and older animals. Stuti et al. (2007) also reported that calves below one year were the most susceptible (65.4\%) followed by the grownups $(34.6 \%)$ and adults $(14.9 \%)$ cattle. The result of the present study also agree with L'Hostis et al. (1996) and Swai et al. (2005), who reported that calves were more susceptible to tick infestation as compared to older members of the young stock. This could be attributed to lower immunity and softer and thinner skin of young animals that could aid in the penetration of mouthparts of ticks for feeding (Sajid, 2007). In contrast, Rony et al. (2010) reported that prevalence of infestation was significantly higher in older animals aged $>8$ years $(71.1 \%)$ followed by adults aged $>2-8$ years $(65.4 \%)$ and the lowest was seen in young aged $\leq 2$ years (47.1\%). Prevalence of ectoparasitic infestation was higher in Wadara and Kuri breeds as compared with the 
Rahaji, Bunaji and Gudali breeds in this study (Table 1). This suggests that none of these breeds was completely resistant to tick infestations as all the breeds were infested at varying levels. Kabir et al. (2011) reported that prevalence of ticks was significantly higher in local cattle $(43.8 \%)$ than the crossbred $(24.1 \%)$ cattle. However, other studies identified a higher prevalence of tick infestation in crossbred cattle of $5-10$ years of age (Sajid et al., 2009). Zebu (Bos indicus) was reported to show some levels of relative resistance to tick infestations as compared with Bos indicus and Bos taurus crosses (Wambura et al., 1998). Higher concentration of serum complements had been suggested to be associated with tick resistance in these breeds. While other studies (Jongejan and Uilenberg, 2004) maintained that tick resistance is a hereditary trait in Bos indicus cattle. The distribution (\%) of tick infestation in different body parts of cattle examined reveals that udder and external genitalia, inner thigh and under tail/perineum were the most tick - infested sites in the body of examined animals (Table 2). This further confirms that ticks prefer to attach and feed on some parts of the body of animals. This finding is in agreement with the work by Opara and Ezeh (2011) in Borno State, Northeastern Nigeria who found that ticks infesting cattle in this area prefer to attach and feed on inner thighs, dew lap, abdomen, legs, udder, dorsum, ear and hump in this order. Asmaa et al. (2014) also reported that udders and external genitalia were the most tick - infested sites $(70.7 \%$ each) followed by neck \& chest $(63.0 \%$ each), inner thighs $(61.1 \%)$, perineum $(41.7 \%)$, ears $(14.6 \%)$ and around eyes (11.7\%). Atif et al. (2012) in the same vein reported that the perineum, udder and external genitalia $(98 \%)$ were the most tick infested sites in cattle followed by dewlap (92\%), inner thighs $(90 \%)$, neck \& back (54\%), tail (26\%), ears (13\%), around eyes (10\%), flanks (4\%) and legs $(2 \%)$ in this order of infestation. These findings could be attributed to the fact that external genitals, perineum and inguinal/groin region of the body are highly supplied with blood and ticks usually prefer thinner and short hair skin for infestation. This helps in easy penetration of mouthparts of ticks into richly vascular area for feeding (Sajid, 2007). This study reveals high prevalence of tick infestation among indigenous cattle breeds in Maiduguri. Tick infestations and tick-borne diseases are associated with reduced production and productivity. Therefore, appropriate control strategies should be instituted by the appropriate authorities to mitigate these losses in production and tick-borne diseases in Maiduguri.

\section{REFERENCES}

1. Agbede RI (1981). A survey of ectoparasites and ectoparasitic condition of animals in Zaria. Nigerian Journal of animal production resources 1 (2): $179-180$.

2. Amoo AJ, Dipeolu OO and Akinboade OA (1984). The prevalence of Boophilus species in southern Nigeria. Laboratory studies on the survivability of their egg and adults. International Journal of Acarology p. 85.

3. Anonymous (1996). Research Inventory Management Systems. Nigerian Livestock Resources Vol. 1. Executive Survey and Atlas. Fed. Dept. Livestock and Pest Control Services, Garki Abuja-Nigeria 1996.

4. Asmaa NM, Elbably MA and Shokier KA (2014). Studies on prevalence, risk indicators and control options for tick infestation in ruminants. Beni - Seuf University Journal of Basic and Applied Sciences 68 - 73.

5. Atif FA, Khan MS, Iqbal HJ, Ali Z and Ullah S (2012). Prevalence of cattle tick infestation in three districts of the Punjab, Pakistan. Pakistan Journal of Science 64: 49.

6. Biswas S (2003). Role of veterinarians in the care and management during harvest of skin in livestock species. In: Proc. National Seminar on Leather Industry in Today's Perspective, Kolkata, India, p. 62 - 64.

7. Bowman AS, Dillwith JW and Sauer JR (1996). Tick salivary prostaglandins: presence, origin and significance. Parasitology Today 12: 388 - 396.

8. De Castro JJ (1997). Sustainable tick and tick borne disease control in livestock improvement in developing countries. Veterinary Parasitology 71: 77-97.

9. De Wall DT (2000). Anaplasmosis control and diagnosis in South Africa. Annals of the New York Academy of Sciences 916: $474-483$.

10. Gwakisa P, Yoshihara K, Long TT, Gotoh H, Amano F and Eiichi M (2001). Salivary gland extract of Rhipicephalus appendiculatus ticks inhibits in Vitro transcription and secretion of cytokines and production of nitric oxide by LPS stimulated JA-4 cells. Veterinary Parasitology 99: 53-61.

11. Hitcheock LF (1993). Resistance of the cattle tick, to benzene hexachloride. Journal of Agricultural Research 29: $41-49$.

12. Islam MS, Rahman SA, Sarker P, and Anisuzzaman Mondal MMH (2009). Prevalence and population density of ectoparasitic infestation in cattle in Sirajgonj district, Bangladesh. Bangladesh Research Publications Journal 2(1): $332-339$. 


\section{H. I. Musa and others}

13. James-Rugu NN and Jidayi S (2004). A survey on the ectoparasites of some livestocks from some areas of Borno and Yobe States. Nigerian Veterinary Journal 25(2): 48-55.

14. Jongejan F and Uilenberg G (1994). Ticks and control methods In: Blancou J, editor. Ectoparasites of animals and control methods. Sci Tech Rev, 13 (4). Paris, France: Office Internationale des Epizooties (OIE) p. 1201 - 1226.

15. Kabir MHB, Mondal MMH, Eliyas M, Mannan MA, Hashem MA and Debnath NC (2011). An epidemiological survey on investigation of tick infestation in cattle at Chittagong District, Bangladesh. African Journal of Microbiology Research 5(4): 346 - 352.

16. L'Hostis M, Bureaud A and Gorenflot A (1966). Female Ixodes ricinus (Acari, Ixodidae) in cattle of Western France: infestation level and seasonality. Veterinary Research 27: $589-597$.

17. Manan A, Khan Z and Ahmad B (2007). Prevalence and identification of ixodid tick genera in frontier region Peshawar. Journal of Agricultural and Biological Science 2(1): 21 - 25.

18. Mohammed AN (1976). Ectoparasites affecting livestock in Nigeria In: Entomology and the Nigeria Economy. Entomological Society of Nigeria p. 13-18.

19. Obadiah HI and Shekaro A (2012). Survey of tick infestation in cattle in Zaria abattoir, Nigeria. Journal of Veterinary Advances 2(2): 81 - 87.

20. Okon EO and Obiekazie AI (1981). Parasites of cattle in Obudu cattle Ranch. Nigerian Veterinary Journal 10(2): $1-4$.

21. Onyali IO, Oluigbo FO and Ajayi ST (1989). Dry season outbreak of Ornithodorus savigny in Gashua, Borno State. Tropical Veterinary Journal 7: $101-103$.

22. Oyenaya VA and Olibajo FO (1977). The measurement of yield, voluntary intake and animal production on tropical pasture. Journal of Animal Science 77: 1- 4

23. Rajput ZI, Hu S, Chen W, Arijo AG and Xiao C (2006). Importance of ticks and their chemical and immunological control in livestock. Journal of Zhejiang University Science 7(11): 912 - 921.

24. RIM (1992). Nigerian Livestock resources. Four volumes report to the Federal Government of Nigeria. Submitted by Resource Inventory Management Limited. 1. Executive Summary and Atlas. 2. National synthesis. 3. State Reports. 4. Urban Reports and commercially managed livestock survey report.

25. Rony SA, Mondal MMH, Begum N, Islam MA and Affroze S (2010). Epidemiology of ectoparasitic infestations in cattle at Bhawal forest area, Gazipur. Bangladesh Journal of Veterinary Medicine 8(1): 27 - 33.

26. Sajid MS (2007). Epidemiology, acaricidal resistance of tick population infesting domestic ruminants. Ph.D thesis, Faisalabad, Pakistan: University of Agriculture, P: 47.

27. Sajid MS, Iqbal Z, Khan MN, Muhammad G and Khan MK (2009). Prevalence and associated risk factors for bovine tick infestation in two districts of lower Punjab, Pakistan. Preventive Veterinary Medicine 92: 386 - 391.

28. Sarkar M (2007). Epidemiology and pathology of ectoparasitic infestation in Black Bengal Goats in Bangladesh. M.Sc. thesis, Department of Parasitology, Bangladesh Agricultural University, Mymensingh.

29. Soulsby EJI (1982). Helminths, Arthropod and Protozoa of Domesticated Animals. $7^{\text {th }}$ edn, Bailliere, Tindall and Cassell Ltd, p.136-778.

30. Stuti V, Yadav CL, Kumar RR and Rajat G (2007). Seasonal activity of Boophilus microplus on large ruminants at an organized livestock farm. Journal of Veterinary Parasitology 21(2): 125 - 128.

31. Swai ES, Mbise AN, Kessy V, Kaaya E, Sanka P and Loomu PM (2005). Farm constraints, cattle disease perception and tick management practices in pastoral Maasai community - Ngorongoro, Tanzania. Livestock Research and Rural Development 17 (2).

32. Thrusfield M (1995). Veterinary epidemiology. $2^{\text {nd }}$ edn, UK: Black Well science Ltd, p. 182 - 198.

33. Wambura PN, Gwakisa PS, Silayo RS and Rugaimukamu EA (1998). Breed - associated resistance to tick infestation in Bos indicus and their crosses with Bos Taurus. Veterinary Parasitology 77: 63-70. 